Japan. J. Med. Sci. Biol., 32, 353-366, 1979

\title{
AUGMENTATION OF DELAYED-TYPE HYPERSENSITIVITY AND RESISTANCE AGAINST ALLOGENEIC OR SYNGENEIC METHYLCHOLANTHRENE-INDUCED TUMORS IN MICE PREIMMUNIZED WITH THE TUMOR EXTRACTS
}

\author{
Shin-IChi TAMURA, Asato KOJIMA and Yasuyuki EGASHIRA \\ Department of Pathology, The National Institute of Health, \\ Kamiosaki, Shinagawa-ku, Tokyo 141
}

(Received, October 8, 1979. Accepted, October, 25, 1979)

\begin{abstract}
SUMMARY: Delayed-type hypersensitivity (DTH) responses against methylcholanthrene-induced fibrosarcomas in $\mathrm{C} 3 \mathrm{H} / \mathrm{He}$ and $\mathrm{BDF}_{1}$ mice were developed in $\mathrm{BDF}_{1}$ mice by sc injection of the respective mitomycin $\mathrm{C}$-treated tumor cells. The DTH responses to the allogeneic and the syngeneic tumor cells were accelerated and enhanced tumor-specifically by priming 7 days previously with $\mathrm{KCl}$ extracts of the respective tumors. The ability in the mice primed with the tumor extracts enhancing the DTH response against the tumor cells could be transferred to recipient mice by the spleen cells, but not by the $\mathrm{T}$-cell-depleted spleen cells.

Rejection of allogeneic tumor was accelerated under the development of accelerated and enhanced DTH response against the allogeneic tumor antigens. Moreover, resistance to syngeneic tumor growth increased significantly with the development of accelerated and enhanced DTH response against the syngeneic tumor antigens. Thus, the augmentation of DTH response by preimmunization with tumor extracts was accompanied by the increased resistance to tumor growth, suggesting that $\mathbf{T}$ cells involved in the augmentation of tumor-specific DTH response play some role in increasing the resistance to tumor growth.
\end{abstract}

\section{INTRODUCTION}

It is well known that the development of specific delayed-type hypersensitivity $(\mathrm{DTH})$ to tumor antigens is correlated with the resistance to tumor growth in several transplantable tumors (Churchill et al., 1968; Halliday and Webb, 1968; Braum et al., 1978). This fact suggests that the augmentation of specific $\mathrm{DTH}$ response to tumor antigens is effective to reinforce the resistance to tumor growth.

Previously, we demonstrated that an sc priming of mice 2 or more days previously with a low dose of SRBC or protein antigens resulted in an acceleration and enhancement of DTH response upon a subsequent application of the same antigen (Tamura and Egashira, 1976; Kojima, Tamura and Egashira, 1979). We further demonstrated that priming of mice with the antigen induced

* This work was supported in part by a Grant-in-Aid for Scientific Research from the Ministry of Education, Science and Culture.

田村慎一・小島朝人・江頭靖之（国立予防衛生研究所 病理部） 
DTH-related $\mathrm{T}$ memory cells which could accelerate DTH response when transferred to recipient mice. On the other hand, little information has been obtained on the development of accelerated and enhanced DTH responses to tumor antigens, which may endow the host mice with an increased resistance to tumor growth.

In the present study, we demonstrated that DTH responses in mice against methylcholanthrene-induced allogeneic and syngeneic tumors were accelerated and enhanced by priming with $\mathrm{KCl}$ extracts of the respective tumors. We also showed that DTH-related memory $\mathrm{T}$ cells, capable of accelerating DTH response against tumor antigens when transferred into recipient mice, were present in the spleen of the mice primed with the tumor extracts. Moreover, we showed that the augmentation of DTH response against tumor antigens was accompanied by the increased resistance of the host mice to tumor growth, suggesting the possible involvement of DTH-related memory $\mathrm{T}$ cells in the reinforcement of tumor immunity.

\section{Materials ANd Methods}

Mice: Eight to 12 weeks' old female $\mathrm{C} 57 \mathrm{BL} / 6 \times \mathrm{DBA} / 2\left(\mathrm{BDF}_{1}\right)$ and $\mathrm{C} 3 \mathrm{H} / \mathrm{He}$ mice were obtained from Shizuoka Agricultural Cooperative Association for Laboratory Animals, Hamamatsu.

Tumors: Fibrosarcomas were induced in $\mathrm{BDF}_{1}$ and $\mathrm{C} 3 \mathrm{H} / \mathrm{He}$ mice by a single sc injection of 3-methylcholanthrene (MCA) $(0.5 \mathrm{mg}$ in $0.05 \mathrm{ml}$ of sesami oil) in the interscapular region of each mouse (Malmgren and Rabson, 1963). They appeared as firm nodules after 3-6 months and were maintained by the serial sc passages of fragments. Two transplantable fibrosarcomas, designated as MCA-1025 and MCA-1204, were induced in $\mathrm{BDF}_{1}$ mice. Another transplantable fibrosarcoma, MCA-407, was induced in $\mathrm{C} 3 \mathrm{H} / \mathrm{He}$ mice.

Tumor cells: Transplanted tumors, removed after 2-3 weeks' growth, were freed of all obvious normal and necrotic tissues and then minced with ophthalmological scissors. The minced fragments were stirred at $37 \mathrm{C}$ for $15 \mathrm{~min}$ in Dulbecco's PBS (DPBS) containing $0.25 \%$ trypsin and $0.2 \%$ glucose. Then, the dispersed tumor cells in the supernatant were filtered through stainless-steel mesh and washed twice by centrifugation in DPBS containing $10 \%$ fetal calf serum (FCS). The remaining tumor fragments were repeatedly trypsinized to obtain more dispersed cells. For the preservation of tumor cells, trypsinized cells were slowly cooled to $-80 \mathrm{C}$ in DPBS with $10 \% \mathrm{FCS}$ and $10 \%$ dimethylsulfoxide (Potter, 1967).

Tumor extracts: Soluble tumor antigens were extracted from tumor tissues with $3 \mathrm{M} \mathrm{KCl}$ by the method of Stevens et al. (1978). Tumor tissue was removed and freed of connective and necrotic tissues. It was then washed several times with PBS and minced into small sections. These were gently homogenized with a glass homogenizer in PBS containing $3 \mathrm{M} \mathrm{KCl}(25 \mathrm{ml} \mathrm{PBS} / \mathrm{g}$ tissue). The mixture was stirred overnight and centrifuged at $40,000 \times \mathrm{g}$ for $20 \mathrm{~min}$; the 
supernatant was decanted and then dialyzed against a large volume of PBS to remove $\mathrm{KCl}$. The dialyzate was centrifuged at $40,000 \times \mathrm{g}$ for $30 \mathrm{~min}$. The supernatant was concentrated in a vacuum dialysis apparatus, sterilized by passage through a Millipore filter $(0.45 \mu \mathrm{m})$ and used as tumor extracts. The protein content of the extract was determined by the method of Lowry et al. (1951) and was used as an index to estimate the relative quantity of antigen in different extract preparations.

Immunization: Mice were each immunized by sc injection of $50 \mu \mathrm{l}$ of tumor extract or tumor cells treated with $50 \mu \mathrm{g} / \mathrm{ml}$ Mitomycin $\mathrm{C}$ (MMC) at $37 \mathrm{C}$ for $60 \mathrm{~min}$ into the nuchal and lumbar regions.

Cell transfer: Spleen cell suspension was prepared as described previously (Kojima et al., 1979). Viable spleen cells $\left(5-10 \times 10^{7}\right)$ were transferred to cyclophosphamide (CY; Endoxan, Shionogi Co., Osaka)-pretreated recipient mice. $\mathrm{CY}$ was injected intraperitoneally in a dose of $100 \mathrm{mg} / \mathrm{kg} 3$ days before the cell transfer. Immediately after the cell transfer, the recipient mice received sc injection of MMC-treated tumor cells.

Removal of $T$ cells from spleen cells: $T$ cells in spleen cell suspensions were removed by treatment with rabbit anti-mouse brain-associated $\theta$ (anti-Ba $\theta$ ) serum and guinea-pig complement $(\mathrm{C})$, as described previously (Kojima et al., 1979).

DTH assay: Tumor-specific DTH response was elicited in immunized mice by injecting $200 \mu \mathrm{g}$ tumor extract absorbed on $50 \mu \mathrm{g}$ aluminium hydroxide gel (alum), prepared by the method of Revoltella and Ovary (1973), in a 25- $\mu 1$ volume into the right-hind footpad of each animal. As a control, 50- $\mu \mathrm{g}$ alum in a $25-\mu 1$ volume was injected into the left-hind footpad. DTH response was determined from the increase in footpad thickness $24 \mathrm{hr}$ after the injection of eliciting antigen, as described previously (Tamura et al., 1973).

Assay of tumor growth: Living allogeneic or syngeneic tumor cells were inoculated subcutaneously into the right-hind footpad of each mouse. The footpad thickness after inoculation of the tumor cells was measured as an index of tumor growth.

\section{Results \\ Induction of Accelerated and Enhanced DTH Response against Allogeneic Tumor}

First, attempts were made to select an effective antigen form of tumor for the induction of $\mathrm{DTH}$ response. $\mathrm{BDF}_{1}$ mice each received an sc injection of various preparations of $\mathrm{C} 3 \mathrm{H} / \mathrm{He}$ tumor (MCA-407) into the nuchal and lumber regions and 7 days later another sc injection of alum-absorbed MCA-407 extract for the elicitation of DTH response into the footpad. As shown in Table I, living cells $\left(1 \times 10^{6}\right)$ and MMC-treated cells $\left(1 \times 10^{6}\right)$ induced significantly high DTH response. Disruption of cells by freezing and thawing destroyed their ability to induce DTH response. Tumor extract $(150 \mu \mathrm{g})$ was also inactive. 
TABLE I

Suitability of various preparations of $\mathrm{C} 3 \mathrm{H} / \mathrm{He}$ tumor for induction of $D T H$ response in $B D F_{1}$ mice

\begin{tabular}{lc}
\hline \multicolumn{1}{c}{$\begin{array}{c}\text { Immunization } \\
\text { with }\end{array}$} & $\begin{array}{c}\text { Footpad swelling } \\
(\times 1 / 100 \mathrm{~mm})\end{array}$ \\
\hline Living cells $\left(1 \times 10^{6}\right)$ & $28.8 \pm 6.6$ \\
MMC-treated cells $\left(1 \times 10^{6}\right)$ & $33.8 \pm 10.7$ \\
Freeze-thawed cells $\left(1 \times 10^{6}\right)$ & $2.8 \pm 1.8$ \\
Freeze-thawed cells in CFA & $10.0 \pm 1.9$ \\
Extract $(150 \mu \mathrm{g})$ & $6.8 \pm 3.3$ \\
Extract in CFA & $13.4 \pm 3.9$ \\
\hline
\end{tabular}

a) $\mathrm{BDF}_{1}$ mice were immunized subcutaneously with various preparations of MCA-induced C3H/He tumor (MCA-407). Freeze-thawed cells $\left(1 \times 10^{6}\right)$ or tumor extract were emulsified with an equal volume of CFA.

b) DTH was elicited by the injection of alum-absorbed MCA407 extract 7 days after immunization. Each value represents the mean footpad swelling of five mice $\pm \mathrm{SE}$ $\left(\times 10^{-2} \mathrm{~mm}\right)$ at $24 \mathrm{hr}$ after injection of the DTH responseeliciting antigen.

TABLE II

Effect of the dose of $\mathrm{C} 3 \mathrm{H} / \mathrm{He}$ tumor extract on the induction of accelerated and enhanced $D T H$ response in $B D F_{1}$ mice

\begin{tabular}{ccc}
\hline $\begin{array}{c}\text { Priming with } \\
\text { extract }(\mu \mathrm{g})\end{array}$ & $\begin{array}{c}\text { Challenge with } \\
\text { MMC-treated cells } \\
\text { Day -7 }\end{array}$ & $\begin{array}{c}\text { Footpad swelling } \\
(\times 1 / 100 \mathrm{~mm}) \\
\text { Day } 4\end{array}$ \\
\hline 0 & + & $51.0 \pm 4.3$ \\
15 & + & $42.5 \pm 7.2$ \\
150 & + & $96.0 \pm 3.3$ \\
1500 & + & $69.0 \pm 9.3$ \\
150 & - & $6.8 \pm 3.3$ \\
\hline
\end{tabular}

a) $\mathrm{BDF}_{1}$ mice were primed subcutaneously with various doses of extracts of MCA-induced C3H/He tumor (MCA-407) on Day -7 .

b) They were challenged subcutaneously with MMC-treated MCA407 cells $\left(1 \times 10^{6}\right)$ on Day 0 .

c) DTH was elicited by the injection of alum-absorbed MCA-407 extract on Day 4 after the challenge. Mean \pm SE.

Disrupted (frozen and thawed) tumor cells in Freund's complete adjuvant (CFA) or tumor extract in CFA induced only a slight DTH response. The results show that the MMC-treated allogeneic tumor cell is a suitable form of the tumor antigen for inducing primary DTH response against the allogeneic tumor.

Next, effect of dose of MCA-407 extract for priming on the development of accelerated and enhanced DTH response against MMC-treated MCA- 407 cells was investigated in $\mathrm{BDF}_{1}$ mice. Mice were primed with various doses $(0-1,500$ $\mu \mathrm{g})$ of MCA-407 extract on Day -7 , and challenged with the MMC-treated cells 


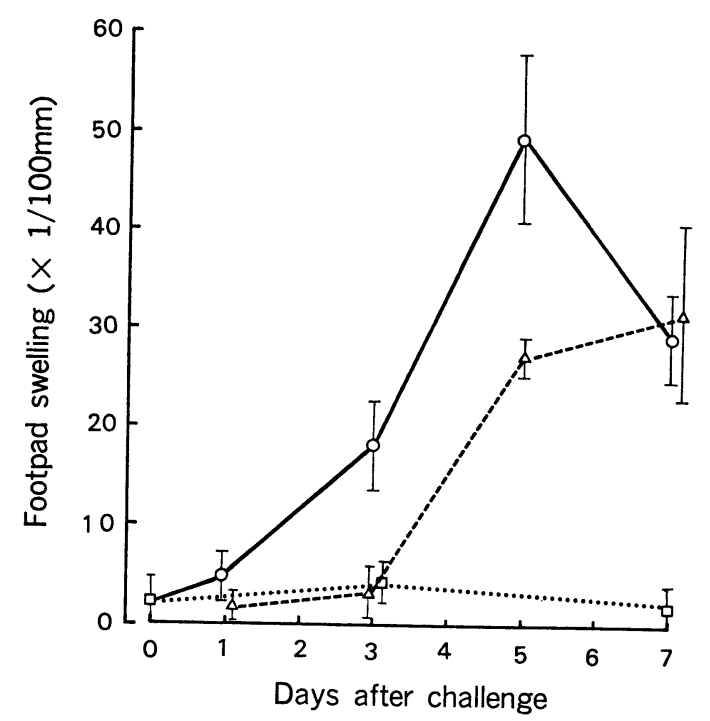

Fig. 1. Kinetics of accelerated and enhanced DTH response after challenge with MMCtreated $\mathrm{C} 3 \mathrm{H} / \mathrm{He}$ tumor (MCA-407) cells $\left(1 \times 10^{6}\right)$ on Day 0 in $\mathrm{BDF}_{1}$ mice primed with MCA407 extract $(150 \mu \mathrm{g})$ on Day $-7(\mathrm{O}-\mathrm{O})$. Kinetics in the control mice given a single injection of the MMC-treated tumor cells on Day $0(\Delta \cdots \Delta)$ and that in those given only a priming injection of the tumor extract on Day -7 ( $\square \cdots \square)$ are also shown. Footpad swelling at $24 \mathrm{hr}$ after injection of the DTH response-eliciting antigen is plotted against the injection time of the antigen. Each value represents the mean of five mice and bars indicate the upper and lower limits of the standard error.

$\left(1 \times 10^{6}\right)$ on Day 0 . Four days after challenge, they received an injection of eliciting antigen into the footpad and $24 \mathrm{hr}$ later their DTH responses were determined. Table II shows that the mice primed with the extracts $(150 \mu \mathrm{g}$ and $1,500 \mu \mathrm{g})$ and challenged with the MMC-treated cells induced higher DTH responses on Day 4 than those given the MMC-treated cells alone, while those primed with the extract $(150 \mu \mathrm{g})$ alone failed to induce DTH response. The results indicate that $\mathrm{DTH}$ response against MMC-treated allogeneic cells is accelerated or enhanced by priming with the tumor extract, and that $150 \mu \mathrm{g}$ of allogeneic tumor extract is a suitable priming antigen dose which can maximally accelerate DTH response against the MMC-treated cells.

Kinetics of accelerated and enhanced DTH response against MCA-407 $\left(\mathrm{C} 3 \mathrm{H} / \mathrm{He}\right.$ tumor) was examined in $\mathrm{BDF}_{1}$ mice. Mice were primed with $150 \mu \mathrm{g}$ MCA-407 extract on Day -7 and challenged with $1 \times 10^{6}$ MMC-treated MCA-407 cells on Day 0. On Days 1, 3, 5 and 7 after challenge, they each received an injection of the eliciting antigen and the footpad swelling was measured $24 \mathrm{hr}$ later. Figure 1 shows the results. Mice given the extract alone failed to show any appreciable DTH response throughout the period. In mice injected with the MMC-treated cells alone on Day 0, DTH appeared on Day 5, reached a maximum level on Day 7. On the other hand, in mice primed with the extract 
on Day -7 and challenged with the MMC-treated cells on Day 0, DTH response appeared 2 days earlier than that in non-primed mice, and reached its maximum on Day 5. The results demonstrate that $\mathrm{DTH}$ response in $\mathrm{BDF}_{1}$ mice against $\mathrm{C} 3 \mathrm{H} / \mathrm{He}$ tumor cells can be accelerated and enhanced by priming in advance with the allogeneic tumor extract.

\section{Effect of Induction of Accelerated and Enhanced DTH Response on Allogeneic Tumor Rejection}

Effect of the induction of augmented DTH response against $\mathrm{C} 3 \mathrm{H} / \mathrm{He}$ tumor (MCA-407) on the rejection of the allogeneic tumor was examined in BDF $_{1}$ mice. Mice were primed with $150 \mu \mathrm{g}$ MCA- 407 extract on Day -10 and challenged with $1 \times 10^{6}$ MMC-treated MCA-407 cells on Day -3 , to induce the augmented state for DTH response. Three days after challenge (Day 0 ), $1 \times 10^{6}$ living MCA-407 cells were inoculated into the right-hind footpad of each $\mathrm{BDF}_{1}$ mouse, and the footpad swelling was measured as an index of tumor size. Figure 2 shows the kinetics of the tumor rejection after inoculation of the tumor cells in the footpad. The tumor size in non-immunized mice increased up to Day 4 after inoculation of the tumor cells, decreased rapidly thereafter and returned to the normal level on Day 12, showing that the allogeneic tumor cells were

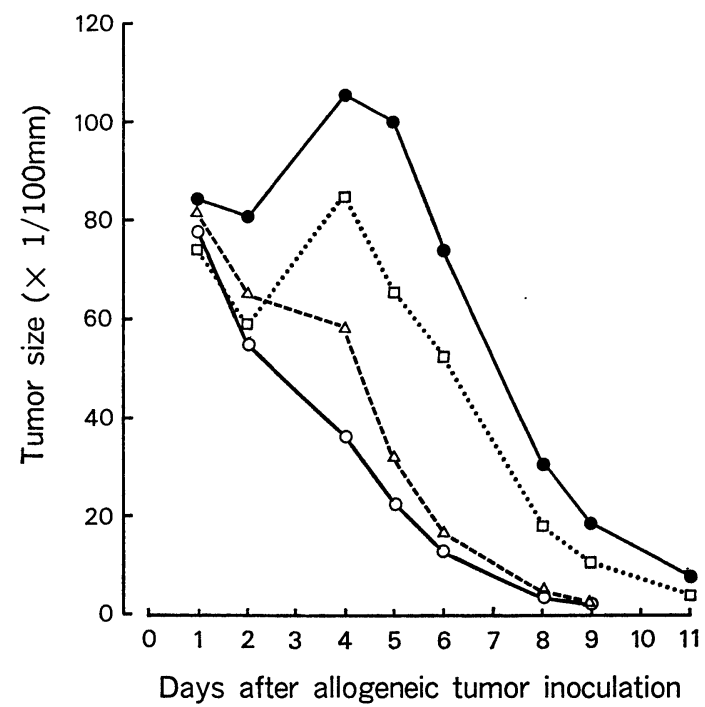

Fig. 2. Kinetics of the rejection of MCA-induced C3H/He tumor (MCA-407) after inoculation of the living tumor cells on Day 0 in BDF $_{1}$ mice primed with the MCA-407 extract $(150 \mu \mathrm{g})$ on Day -10 and challenged with the MMC-treated MCA-407 cells $\left(1 \times 10^{6}\right)$ on Day $-3(\mathrm{O}-\mathrm{O})$. Kinetics of the tumor rejection in the mice given a single injection of the MMCtreated cells on Day $-3(\Delta \cdots \Delta)$, that in those given only a priming injection of tumor extracts on Day $-10(\square \cdots \square)$, and that in normal BDF $_{1}$ mice (-0) are also shown. Living MCA-407 cells $\left(1 \times 10^{8}\right)$ were inoculated into the hind-footpad of $\mathbf{B D F}_{1}$ mice on Day 0 and the footpad swelling was measured as an index of tumor size. Each value represents the mean of five mice. 
rejected within 12 days in non-immunized mice. In the mice which had been immunized either with the extract alone, with the MMC-treated cells alone, or with both, MCA-407 cells were rejected more rapidly than those in nonimmunized mice and the rate of the rejection increased in that order. The results suggest that the induction of $\mathrm{DTH}$ response in $\mathrm{BDF}_{1}$ mice against the $\mathrm{C} 3 \mathrm{H} / \mathrm{He}$ tumor cells is correlated with the rapid rejection of the allogeneic tumor cells, and that the induction of the augmented DTH response is also correlated with a more rapid rejection of the allogeneic cells.

\section{Induction of Accelerated and Enhanced DTH Response against Syngeneic Tumor}

Experiments were made to demonstrate the existence of accelerated and enhanced $\mathrm{DTH}$ response in $\mathrm{BDF}_{1}$ mice against MCA-induced syngeneic fibrosarcoma (MCA-1025). BDF $_{1}$ mice were primed subcutaneously with $150 \mu \mathrm{g}$ MCA-1025 extract on Day -7 and challenged subcutaneously with the MMCtreated MCA-1025 cells $\left(1 \times 10^{6}\right)$ on Day 0 . On Days $0,1,2,3,5$ and 7 after challenge, mice were elicited for DTH responses against MCA-1025. Figure 3 shows the kinetics of accelerated and enhanced DTH response. Mice receiving $150 \mu \mathrm{g}$ of tumor extract alone induced a moderate level of DTH response from Day 0 to Day 7 after the injection of the tumor extract. In mice immunized with the MMC-treated tumor cells alone, the DTH response appeared first on Day 3 and reached the maximum on Day 7, the level of which was higher than that in those given tumor extract alone. On the other hand, in mice

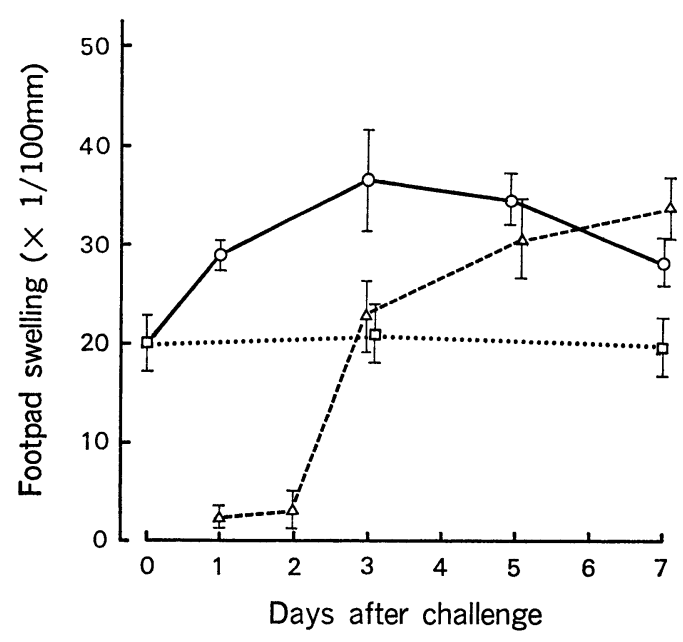

Fig. 3. Kinetics of accelerated and enhanced DTH response after challenge with MMCtreated $\mathrm{BDF}_{1}$ tumor $(\mathrm{MCA}-1025)$ cells $\left(1 \times 10^{\circ}\right)$ on Day 0 in $\mathrm{BDF}_{1}$ mice primed with the same tumor extract $(150 \mu \mathrm{g})$ on Day $-7(\mathrm{O}-\mathrm{O})$. Kinetics in mice given the MMC-treated tumor cells alone on Day $0(\Delta \cdots \Delta)$, and that in those given the tumor extract alone on Day -7 $\square \cdots \square) \quad$ are also shown. For other details, see legends to Fig. 1. 
TABLE III

Specificity of induction of accelerated and enhanced $D T H$ response in $B D F_{1}$ mice

\begin{tabular}{lcrr}
\hline \multirow{2}{*}{$\begin{array}{c}\text { Priming } \\
\text { Day }-7\end{array}$} & $\begin{array}{c}\text { Challenge }^{(b)} \\
\text { Day 0 }\end{array}$ & \multicolumn{2}{c}{$\begin{array}{c}\text { Footpad swelling } \\
(\times 1 / 100 \mathrm{~mm})\end{array}$} \\
\cline { 3 - 4 } & & \multicolumn{1}{c}{ Day 3 } & Day 5 \\
\hline MCA-1025 & MCA-1025 & $14.0 \pm 1.4$ & $22.6 \pm 2.0$ \\
MCA-1204 & MCA-1025 & $6.2 \pm 2.5$ & $13.0 \pm 1.6$ \\
MCA-407 & MCA-1025 & $5.2 \pm 1.3$ & $14.3 \pm 3.3$ \\
MCA-1025 & MCA-1025 & $5.2 \pm 1.7$ & $14.2 \pm 3.2$ \\
MCA-1204 & - & $5.5 \pm 2.7$ & $6.4 \pm 1.3$ \\
MCA-407 & - & $1.8 \pm 1.4$ & $1.0 \pm 2.5$ \\
\hline
\end{tabular}

a) $\mathrm{BDF}_{1}$ mice were primed with extracts $(150 \mu \mathrm{g})$ of $\mathrm{MCA}$-induced $\mathrm{BDF}_{1}$ tumors (MCA-1025 and MCA-1204) or C3H/He tumor (MCA-407) on Day -7 .

b) They were challenged with MMC-treated MCA-1025 cells $\left(5 \times 10^{5}\right)$ on Day 0.

c) DTH was elicited by the injection of alum-absorbed MCA-1025 extract on Day 3 and on Day 5 after the challenge. Mean \pm SE.

primed with the extract and challenged with the MMC-treated cells, the level of DTH response on Day 0 was the same as that found in those given the extract alone on Day 7, and on Days 1 and 2 after challenge an accelerated DTH response was observed, 2 days earlier than the primary DTH response against the MMC-treated cells. These results indicate that $\mathrm{BDF}_{1}$ mice primed previously with the syngeneic tumor extract can induce an accelerated and enhanced DTH response upon challenge with the MMC-treated syngeneic tumor cells.

Next experiments were made to determine whether the induction of an accelerated and enhanced $\mathrm{DTH}$ response was tumor-specific. $\mathrm{BDF}_{1}$ mice were primed with extracts $(150 \mu \mathrm{g})$ of two syngeneic tumors, MCA-1025 and MCA1204, and allogeneic tumor MCA-407 on Day -7, and challenged with MMCtreated MCA-1025 cells $\left(5 \times 10^{5}\right)$ on Day 0 . They were then tested for DTH response by the injection of alum-absorbed MCA-1025 extract into the footpad on Days 3 and 5 after challenge. Table III shows that DTH response against MMC-treated MCA-1025 cells is accelerated and enhanced in mice primed with MCA-1025 extract, but not in those primed with MCA-1204 or MCA-407 extract. These results show that an accelerated and enhanced DTH response is induced tumor-specifically.

\section{Transfer of the Ability to Accelerate DTH Response by Splenic $T$ Cells}

The spleen cells of $\mathrm{BDF}_{1}$ mice primed with syngeneic tumor (MCA-1025) extract were examined for their ability to accelerate DTH response against 
TABLE IV

Transfer of the ability to accelerate and enhance DTH response by spleen cells to CY-pretreated recipient mice

\begin{tabular}{ccc}
\hline $\begin{array}{c}\text { Spleen cell donors } \\
\text { primed with } \\
\text { Day }-7\end{array}$ & $\begin{array}{c}\text { Recipients }^{b)} \\
\text { challenged } \\
\text { Day 0 }\end{array}$ & $\begin{array}{c}\text { Footpad swelling } \\
(\times 1 / 100 \mathrm{~mm}) \\
\text { Day 3 }\end{array}$ \\
\hline None & + & $17.2 \pm 4.2^{d)}$ \\
Extract & + & $19.4 \pm 6.4$ \\
Extract & + & $45.2 \pm 3.6$ \\
\hline
\end{tabular}

a) Spleen cells $\left(7 \times 10^{7}\right)$ from $\mathrm{BDF}_{1}$ mice primed with the syngeneic tumor (MCA-1025) extract $(150 \mu \mathrm{g})$ on Day -7 were transferred on Day 0 to recipient mice which had been treated with CY (100 $\mathrm{mg} / \mathrm{kg}) 3$ days before the cell transfer.

b) The recipient mice were challenged with MMC-treated MCA-1025 cells $\left(1 \times 10^{6}\right)$ immediately after the cell transfer.

c) DTH was elicited by the injection of alum-absorbed MCA-1025 extract on Day 3 after the cell transfer. Mean $\pm S E$.

d) DTH response in the recipient mice given no cells.

\section{TABLE V}

Effect of treatment of primed spleen cells with anti-BaO serum and complement $(C)$ on their ability to accelerate DTH response

\begin{tabular}{ccc}
\hline $\begin{array}{c}\text { Spleen cell donors } \\
\text { primed with }\end{array}$ & $\begin{array}{c}\text { Treatment } \\
\text { with }\end{array}$ & $\begin{array}{c}\text { Footpad swelling } \\
(\times 1 / 100 \mathrm{~mm})\end{array}$ \\
\hline None & - & $4.2 \pm 2.5$ \\
Extract & - & $24.6 \pm 2.3$ \\
Extract & $\mathrm{NRS}+\mathrm{C}$ & $21.6 \pm 3.7$ \\
Extract & Anti-Ba $\theta$ serum $+\mathrm{C}$ & $5.8 \pm 3.1$ \\
\hline
\end{tabular}

a) Spleen cell suspension was prepared from $\mathrm{BDF}_{1}$ mice primed with syngeneic tumor (MCA-1025) extract $(150 \mu \mathrm{g})$ on Day -7 .

b) The spleen cell suspension $\left(7 \times 10^{7}\right)$ was treated with anti-Ba $\theta$ serum and complement on Day 0 , and then transferred to CY-pretreated recipients, which were challenged with MMC-treated MCA-1025 cells $\left(1 \times 10^{6}\right)$ immediately after the cell transfer.

c) DTH was elicited on Day 3 after the cell transfer. Mean $\pm \mathrm{SE}$.

the MMC-treated MCA-1025 cells in cell-transfer experiments. Spleen cells $\left(7 \times 10^{7}\right)$ from mice primed with $150 \mu \mathrm{g}$ MCA-1025 extract on Day -7 were transferred to CY-pretreated recipient mice on Day 0. As a control, normal spleen cells were transferred. Immediately after the transfer, recipients were challenged with the MMC-1025 cells $\left(1 \times 10^{6}\right)$. On Day 3 after cell transfer, the recipient mice were injected with the DTH response-eliciting antigen. Table IV shows that a significantly higher DTH response was detected on Day 3 in the recipients given the spleen cells from the mice primed with the tumor extract than that in those given no cells or normal spleen cells, or no challenge antigen. The results indicate that the cells, being responsible for the acceleration and enhancement 
of DTH response against syngeneic tumor cells, are induced in the spleen of the mice primed with the tumor extract.

Subsequent experiments were performed to examine whether the ability of the spleen cells of the extract-primed mice to accelerate DTH response was dependent on $\mathrm{T}$ cells. Spleen cells from $\mathrm{BDF}_{1}$ mice primed with MCA-1025 extract on Day -7 were treated with rabbit anti-Ba $\theta$ serum and complement, or with normal rabbit serum and complement as a control on Day 0. Then the treated cells were transferred on Day 0 to CY-pretreated recipients, which received MMC-treated MCA-1025 cells immediately after cell transfer. The recipient mice were tested for DTH response on Day 3 after transfer. Table V shows that the primed spleen cells treated with anti-Ba $\theta$ serum and complement could no longer transfer the ability to accelerate DTH response to the recipient mice, although the non-treated spleen cells or the spleen cells treated with normal rabbit serum (NRS) and complement could transfer it. These results show that $T$ cells in the spleen are responsible for the induction of accelerated and enhanced DTH response against syngeneic tumor.

\section{Effect of the Induction of Accelerated and Enhanced DTH Response on Syngeneic Tumor Growth}

Effect of the induction of an accelerated and enhanced DTH response against syngeneic tumor (MCA-1025) on the tumor growth and the tumor incidence was examined. Mice were primed with MCA-1025 extract on Day -10 and challenged with $1 \times 10^{6}$ MMC-treated MCA-1025 cells on Day -3 to induce an accelerated and enhanced DTH response. Three days after challenge (Day 0 ), living MCA-1025 cells $\left(5 \times 10^{5}\right)$ were inoculated subcutaneously into the righthind footpad of each mouse, and the footpad swelling was measured as an index of the tumor growth. Figure 4 shows a representative result of tumor growth after inoculation of syngeneic tumor cells into the footpad. The footpad swelling in normal mice continued to increase until the deaths of the tumor-bearing mice, showing that normal mice failed to reject $5 \times 10^{5}$ tumor cells inoculated into the footpad. On the other hand, the tumor growth was suppressed slightly in mice primed with the extract alone on Day -10, and more markedly in those immunized with the MMC-treated tumor cells on Day -3. Moreover, it was completely inhibited in those primed with the extract and challenged with the MMC-treated cells. This was confirmed in another experiment of tumor incidence shown in Table VI. Thus the tumor incidence in mice immunized with the tumor extract alone, with the MMC-treated cells alone, or with both was 8 out of 15,5 out of 15 , and 2 out of 15, respectively, whereas almost all non-immune mice developed tumors (13 out of $15 ; 90 \%$ lethality with a dose of $5 \times 10^{5}$ viable tumor cells). These results, together with that shown in Fig. 3, seem to indicate that syngeneic tumor growth or syngeneic tumor incidence decreases with an increase of the intensity of specific DTH response against the tumor in immunized mice. Thus the induction of augmented DTH response is correlated with the increased resistance to tumor growth. 


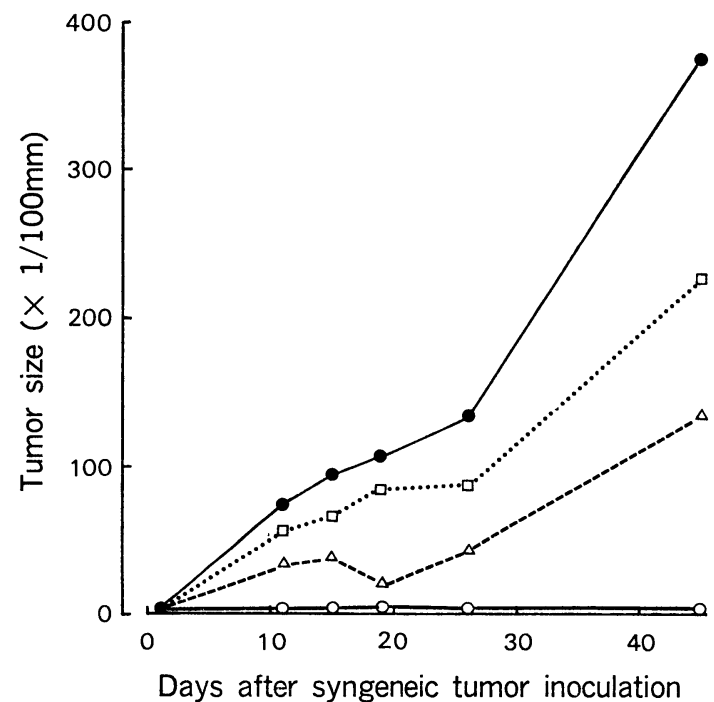

Fig. 4. Kinetics of the growth of $\mathrm{MCA}$-induced $\mathbf{B D F}_{1}$ tumor (MCA-1025) after inoculation of the living tumor cells on Day 0 in the syngeneic mice primed with MCA-1025 extract $(150 \mu \mathrm{g})$ on Day -10 and challenged with $1 \times 10^{\circ}$ MMC-1025 cells on Day $-3(\mathrm{O}-\mathrm{O})$. Kinetics of the tumor growth in mice given the MMC-treated tumor cells on Day $-3(\Delta \cdots \Delta)$, that in those given the tumor extract alone on Day $-10(\square \cdots \square)$ and that in non-immunized mice (-O) are also shown. Living MCA-1025 cells $\left(5 \times 10^{5}\right)$ were inoculated into the hind-footpad of syngeneic mice on Day 0 and the footpad swelling was measured as an index of the tumor size by days. Each value represents the mean of five mice.

TABLE VI

Suppression of MCA-induced tumor growth in $B D F_{1}$ mice under the induction of accelerated and enhanced DTH response to the syngeneic tumor

\begin{tabular}{cccc}
\hline $\begin{array}{c}\text { Priming } \\
\text { Day }-10\end{array}$ & $\begin{array}{c}\text { Challenge } \\
\text { Day }-3\end{array}$ & $\begin{array}{c}\text { Inoculation }^{c)} \\
\text { of tumor } \\
\text { Day 0 }\end{array}$ & $\begin{array}{c}\text { Tumor }^{d)} \\
\text { incidence } \\
\text { Day 45 }\end{array}$ \\
\hline- & - & + & $13 / 15$ \\
+ & - & + & $8 / 15$ \\
- & + & + & $5 / 15$ \\
+ & + & + & $2 / 15$ \\
\hline
\end{tabular}

a) $\mathrm{BDF}_{1}$ mice were primed 10 days previously with extract $(150 \mu \mathrm{g})$ of MCA-induced $\mathrm{BDF}_{1}$ tumor (MCA-1025).

b) They were challenged 3 days previously with MMC-treated MCA-1025 cells $\left(1 \times 10^{6}\right)$.

c) They were then inoculated with the living MCA-1025 cells $\left(5 \times 10^{5}\right)$ into the right hind-footpad on Day 0.

d) Number of mice with tumor/number of mice inoculated with living MCA-1025 cells. The incidence was determined on Day 45 after inoculation of the tumor cells. 


\section{Discussion}

Several investigators have found that the animals immunized with tumor antigens induced a specific DTH response against the tumor antigens, accompanying with the resistance to tumor growth (Churchill et al., 1968; Halliday and Webb, 1969; Braum et al., 1978). The finding indicates a correlation between DTH response and tumor immunity and suggests that an augmentation of DTH response against tumor antigens may reinforce the tumor immunity. Therefore, we tried to augment DTH response against tumor antigens, and examined the effect of augmentation of $\mathrm{DTH}$ response on the protection against the tumors.

The fact that DTH response is augmented in animals primed with an antigen upon a subsequent application of the same antigen has been described for several antigens including proteins (Crowle and $\mathrm{Hu}, 1969$ ), a contact sensitizing agent (Crowle and $\mathrm{Hu}, 1964$ ), bacteria (Collins and Mackaness, 1970; North and Deissler, 1975) and red blood cells (Tamura and Egashira, 1976). In the present experiments, we first demonstrated that an augmented DTH response could also be induced against allogeneic or syngeneic chemically-induced tumors. The augmented response was induced tumor-specifically in the mice primed with

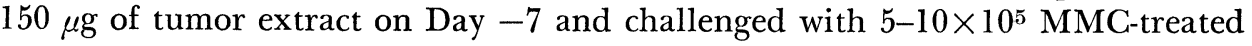
tumor cells on Day 0, and it appeared 2 days earlier than in the non-primed mice (Figs. 1 and 3, Table III). The properties of augmented DTH responses against tumors are similar to those against sheep red blood cells or ovalbumin, as described previously (Tamura and Egashira, 1976; Kojima et al., 1979). We showed also that the ability in the mice primed with tumor extract accelerating DTH response was transferable by the splenic T cells (Tables IV and V). The finding that splenic $T$ cells in primed mice are involved in induction of the augmented DTH response is consistent with that in a previous paper (Kojima et al., 1979), in which we described that these $\mathrm{T}$ cells, designated as DTH-related memory $T$ cells, probably belonged to a different subset of $T$ cells from effector $\mathrm{T}$ cells for DTH response. Further studies are in progress to characterize the memory $\mathrm{T}$ cells for the augmentation of $\mathrm{DTH}$ response against tumors.

We examined the effect of augmentation of $\mathrm{DTH}$ response on allogeneic or syngeneic tumor rejection. The allogeneic tumor cells were rejected in mice immunized with either tumor extract alone, MMC-treated tumor cells alone, or both at a higher rate, which increased in that order, than in non-immunized mice (Fig. 2). Thus, rejection of allogeneic tumor seemed to be accelerated with the increase in the intensity of the specific DTH response against the allogeneic tumor in immunized mice. Moreover, growth of the syngeneic tumor inoculated in the footpad was suppressed slightly in the mice immunized with the tumor extract alone, more markedly in those given the MMC-treated tumor cells alone and almost completely in those given both (Fig. 4). The tumor incidence also decreased in that order (Table VI). Thus, the resistance to syngeneic tumor growth seemed to have increased in parallel to the increase in the intensity of 
specific DTH response against the syngeneic tumor in immunized mice. These findings suggest that the induction of augmented DTH responses against tumor antigens may contribute to the reinforcement of the resistance to tumor growth in the transplantable tumor system.

In the present experiments, we showed that memory $T$ cells must be involved in the augmentation of tumor-specific DTH response (Tables IV and V), which seemed to be related to the reinforcement of tumor immunity (Fig. 4, Table VI), suggesting that the DTH-related memory $\mathrm{T}$ cells may play some role in the protection against tumors. We, however, have not obtained any direct evidence showing the role of DTH-related memory $\mathrm{T}$ cells or the roles of other cells involved in DTH response in the rejection of tumors. There seem to be several possible explanations concerning the significance of induction of specific DTH responses in the tumor rejection. One explanation is that some of lymphokines derived from the DTH-related, tumor-specific effector $\mathrm{T}$ cells may activate macrophages to kill tumor cells (Evans and Alexander, 1970). An alternative assumption is that effector cells for cytotoxic $T$ lymphocyte (CTL) response involved in graft rejection (Cerottini and Brunner, 1974; MacDonald, Cerottini and Brunner, 1974; Delustro and Haskill, 1978) may be induced efficiently under the induction conditions of DTH-related cells. A third possibility is that helper $\mathrm{T}$ cells, which develop simultaneously with the induction of DTH-related memory $T$ cells (Tamura and Egashira, 1976), may be involved in the increased induction of CTL responses to reject tumors (Cantor and Boyse, 1975; Eyfe and Finke, 1979). To solve these problems, it seems important to analyze the roles of memory $\mathrm{T}$ cells and of other cells involved in $\mathrm{DTH}$ response against tumor. Further studies on the roles of these cells in tumor rejection are currently in progress.

\section{ACKNOWLEDGEMENTS}

We wish to express our appreciation to Mr. K. Yaginuma for his technical assistance, Mrs. K. Miyanomae for her animal care and Miss M. Kimura for her assistance in preparation of the manuscript.

\section{REFERENCES}

Braum, D. P., Hengst, J. C. D., Mokyr, M. B. and Dray, S. (1978): Antitumor immunity in strain 2 guinea pigs immunized with potassium chloride extracts of $\mathrm{L}_{2} \mathrm{C}$ tumor cells. J. Nat. Cancer Inst., 60, 899-903.

Cantor, H. AND Boyse, E. A. (1975): Functional subclasses of T lymphocytes bearing different $\mathrm{Ly}$ antigens. II. Cooperation between subclasses of $\mathrm{Ly}^{+}$cells in the generation of killer activity. J. Exptl. Med., 141, 1390-1399.

Cerottini, J.-C. ANd Brunner, K. T. (1974): Cell-mediated cytotoxicity, allograft rejection, and tumor immunity. Adv. Immunol., 18, 67-132.

Churchill, W. H. JR., Rapp, H. J., Kronman, B. S. and Borsos, T. (1968): Detection of antigens of a new diethylnitrosamine-induced transplantable hepatoma by delayed hypersensitivity. J. Nat. Cancer Inst., 41, 13-29.

Collins, F. M. And Mackaness, G. B. (1970): The relationship of delayed hypersensitivity to 
acquired antituberculous immunity. I. Tuberculin sensitivity and resistance to reinfection in BCG-vaccinated mice. Cell. Immunol., 1, 253-265.

Crowle, A. J. AND HU, C. C. (1969): Investigation of the mechanism by which "enhancing" antiserum prevents induction of delayed hypersensitivity to protein antigens in mice. J. Allergy, 43, 209-223.

Crowle, A. J. And Hu, C. C. (1964): Duration of some cutaneous hypersensitivity in mice. J. Immunol., 93, 132-139.

Delustro, F. And Haskill, J. S. (1978): In situ cytotoxic T cells in a methylcholanthrene-induced tumor. J. Immunol., 121, 1007-1009.

Evans, R. And Alexander, P. (1970): Mechanism of immunologically specific killing of tumor cells by macrophages. Nature, 228, 620-622.

Eyfe, D. A. ANd Finke, J. H. (1979): Soluble helper factor(s) participates in the generation of cell mediated cytotoxicity directed against syngeneic tumor cells. J. Immunol., 122, 11561161.

Halliday, W. J. and Webb, M. (1969): Delayed hypersensitivity to chemically induced tumors in mice and correlation with an in vitro test. J. Nat. Cancer Inst., 43, 141-149.

Kojima, A., Tamura, S.-I. AND Egashira, Y. (1979): Regulatory mechanism of delayed-type hypersensitivity in mice. I. Properties of memory cells and suppressor cells for delayed-type hypersensitivity against ovalbumin. Cell. Immunol., 45, 61-73.

Lowry, O. H., Rosebrough, N. J., Farr, A. L. And Randall, R. J. (1951): Protein measurement with the folin phenol reagent. J. Biol. Chem., 193, 265-275.

MacDonald, H. R., Cerottini, J.-C. And Brunner, K. T. (1974): Generation of cytotoxic T lymphocytes in vitro. III. Velocity sedimentation studies of the differentiation and fate of effector cells in long-term mixed leukocyte cultures. J. Exptl. Med., 140, 1511-1521.

Malmgren, R. A. ANd Rabson, A. S. (1963): Failure of inoculation with polyoma virus to influence chemical carcinogenesis in mice. J. Nat. Cancer Inst., 30, 203-206.

North, R. J. ANd Deissler, F. J. (1975): Nature of "memory" in T-cell-mediated antibacterial immunity: Cellular parameters that distinguish between the active immune response and a state of "memory". Infect. Immun., 12, 761-767.

Potter, M. (1967): The plasma cell tumors and myeloma proteins of mice. In Methods in Cancer Research, Busch. H. [ed.], 2, p. 105. Academic Press Inc., New York.

Revoltella, R. AND Ovary, Z. (1973): Preferential production of rabbit reagenic antibodies. Int. Arch. Allergy Appl. Immunol., 36, 283-289.

Stevens, R. H., Brooks, G. P., Osborne, J. W., Hoffman, K. L. and Lawson, A. J. (1978): Lymphocyte cytotoxicity in X-irradiation-induced rat small bowel adenocarcinoma. III. Blocking by $3 \mathrm{M}$ KCl extract. J. Immunol., 120, 335-339.

Tamura, S.-I. AND Egashira, Y. (1976): Cellular and humoral immune responses in mice. III. Acceleration of delayed hypersensitivity response by presensitization with suboptimal dose of antigen. Immunology, 30, 705-713.

Tamura, S.-I., Kurata, T., Sugimoto, M. and Egashira, Y. (1973): Cellular and humoral immune responses in mice. I. Development of delayed-type footpad swelling against sheep erythrocytes and its suppression by intraperitoneal administration of the antigen. Japan. J. Med. Sci. Biol., 26, 161-168. 